\title{
日本循環器学会指定 循環器研修関連施設
}

\section{北海道地区}

岩見沢市立総合病院

木原循環器科内科医院

栗山赤十字病院

厚生年金事業振興団登別厚生年金病院

厚生連総合病院遠軽厚生病院

国立療養所西札幌病院

国家公務員共済組合連合会幌南病院

札幌徳洲会病院

市立芦別病院

市立汇別総合病院

砂川市立病院

総合病院北見赤十字病院

総合病院伊達赤十字病院

滝川市立病院

北海道社会事業協会帯広病院

美唄労多病院

留萌市立総合病院

労働福祉事業団釧路学災病院

$$
\text { 東 北地区— }
$$

《青森県》

十和田市立中央病院

《岩手県》

岩手県立江刺病院

金石市民病院

盛岡赤十字病院

《宮城県》

総合病院仙台赤十字病院

《秋田県》

市立秋田総合病院

本荘第一病院

山本組合総合病院

労働福祉事業団 秋田労災病院

《山形県》

財団法人三友堂病院

長井市立総合病院

《福島県》

医療法人辰星会枡記念病院

医療法人福島厚生会福島第一病院

財団法人白检会総合会津中央病院

財団法人湯浅報恩会寿泉堂綜合病院

総合保原中央病院

原町市立病院

労働福祉事業団福島学災病院

\section{関東甲信越地区}

《茨城県》

石岡市医師会病院

茨城西南医療センタ一病院

医療法人社団輝蜂会東取手病院

医療法人社団常仁会牛久愛和総合病院

医療法人貞心会西山堂病院

財団法人筑波学園病院

社会福祉法人恩賜済生会波崎済生病院

総合守谷第一病院

つくば双愛病院

水戸赤十字病院

《栃木県》

上都賀総合病院

佐野厚生総合病院
《群馬県》

桐生厚生総合病院

前橋赤十字病院

《埼玉県》

春日部市立病院

春日部秀和病院

埼玉医療生活協同組合羽生病院

埼玉協同病院

埼玉県済生会栗橋病院

社団法人東松山医師会病院

草加市立病院

《千葉県》

安房医師会病院

川崎製鉄健康保険組合千葉病院

国保直営総合病院君津中央病院

国立習志野病院

千葉県救急医療センター

千葉市立病院

《東京都》

板橋区医師会病院

医療法人財団大和会東大和病院

医療法人社団大坪会 東和病院

医療法人財団荻窪病院

医療法人社団慈敬会府中医王病院

医療法人社団明芳会板橋中央総合病院

岩井整形外科内科病院

青梅市立総合病院

公立阿伎留病院

国家公務員共済組合連合会立川病院

財団法人朝日生命成人病研究所附属病院

社会福祉法人慈生会慈生会病院

(社)至誠會第二病院

多摩丘陵病院

東京健生病院

東京都立大久保病院

日本赤十字社東京都支部大森赤十字病院

博慈会記念総合病院

《神奈川県》

医療法人徳洲会茅ヶ崎徳洲会総合病院

神奈川リハビリテーション病院

川崎市立井田病院

国立横須賀病院

国家公務員共済組合連平塚共済病院

済生会横浜市南部病院

社団法人日本厚生団長津田厚生総合病院

聖テレジア病院

東芝林間病院

東名厚木病院

平塚市民病院

三菱重工大倉山病院

横浜市立市民病院

《山梨県》

国立甲府病院

《長野県》

飯網行政組合飯綱病院

組合立諏訪中央病院

国立長野病院

佐久市立国保浅間総合病院

昭和伊南総合病院

市立大町総合病院

諏訪共立病院

諏訪赤十字病院
豊科赤十字病院

長野県厚生連佐久総合病院

丸の内病院循環器センター

《新潟県》

医療法人知命堂病院

医療法人嵐陽会三之町病院

佐渡厚生連佐渡総合病院

白根健生病院

新潟県厚生農協組合連㺫羽郡総合病院

新潟県厚生連長岡中央綜合病院

新潟県厚生連村上総合病院

新潟県立吉田病院

新潟労災病院

見附市立成人病センター病院

$$
\text { 東 海 地区 }
$$

《岐阜県》

朝日大学歯学部附属村上記念病院 医療法人社団友愛会岩砂病院第一

岐阜勤労者医療協会みどり病院

岐阜社会保険病院

郡上中央病院

国民健康保険関ヶ原病院

総合病院中津川市民病院

博愛会病院

美濃市立美濃病院

JA 岐卓厚生連総合病院 昭和病院

JA 岐阜厚生連総合病院中濃病院

《静岡県》

共立蒲原総合病院

共立榛原総合病院

国立浜松病院

清水㕌生病院

清水市立病院

社会保険浜松病院

総合病院静岡厚生病院

町立浜岡総合病院

浜松赤十字病院

富士宮市立病院

烍津市立総合病院

《愛知県》

医療法人松陽会松浦病院

公立尾陽病院

社会福祉法人聖霊会聖霊病院

高浜市立病院

豊川市民病院

名古屋市厚生院

名古屋市總合リハビリテーションセンター附属病院

名古屋市立東市民病院

名古屋市立城北病院

名古屋市立守山市民病院

碧南市民病院

《三重県》

青木内科宫口循環器科

鉿鹿回生総合病院

三重県厚生連大台厚生病院

三重県立志摩病院

北陸 地 区

《富山県》

北川内科クリニック

富山労災病院 
头見市民病院

《石川県》

石川県済生会金沢病院

加賀山中医療施設組合公立加賀中央病院 国立山中病院

辰口芳珠記念病院

《福井県》

医療法人初生会福井中央クリニック 公立小浜病院

\section{近 畿 地 区}

《滋賀県》

医療法人誠光会草津総合病院

国立八日市病院

《京都府》

(社)京都保健会京都民医連中央病院 西京都病院

《大阪府》

浅香山病院

石切生喜病院

泉大津市立病院

茨木医誠会病院

医療法人医誠会医誠会病院

医療法人恵生会病院

医療法人マックシール巽病院

医療法人守田会オリオノ和泉病院

医療法人友愛会松本病院

うえに病院

大阪回生病院

大阪逓信病院

国家公務員共済組合連合会京阪奈病院

山弘会上山病院

市立池田病院

特定医療法人徳洲会岸和田徳洲会病院 西淀病院

友紘会総合病院

《兵庫県》

医療法人川崎病院

医療法人財団済美会総合病院昭和病院

公立社総合病院

公立神崎総合病院

国立療養所兵庫中央病院

桜が丘ホスピテル

高砂市民病院

姫路赤十字病院

兵庫県立西宮病院

《奈良県》

医療法人医仁会平井病院

医療法人高清会高井病院

医療法人和幸会阪奈中央病院

東生駒病院

《和歌山県》

国保橋本市民病院

済生会和歌山病院

\section{中 国地 区}

《鳥取県》

西伯町国民健康保険西伯病院

鳥取県立中央病院

国民健康保険智頭病院

《島根県》

済生会江津総合病院

国立浜田病院

総合病院益田赤十字病院

《岡山県》

総合病院岡山協立病院

《広島県》

医療法人清幸会土肥病院

公立学校共済組合中国中央病院

国立療盖所広島病院

総合病院庄原赤十字病院

福島生協病院

《山口県》

大島郡 (国保)診療施設組合大島東部病院

小野田赤十字病院

下関市医師会病院

社会保険下関厚生病院

綜合病院山口赤十字病院

山口労災病院

四国地区

《徳島県》

医療法人雙立会碩心館病院

《香川県》

香川医療生活協同組合高松平和病院

香川県立津田病院

香川労苂病院

屋島総合病院

《愛媛県》

医療法人滴水会吉野病院

愛媛労荻病院

総合病院松山市民病院

《高知県》

厚生年金高知リハビリテーション病院 高知県立安芸病院

高知県立幡多け九みん病院

土佐市立士佐市民病院

九 州 地 区

《福岡県》

系島医師会病院

医療法人社団高邦会高木病院

医療法人徳洲会福岡徳洲会病院

北九州市立八幡病院

久留米リハビリテーション病院

健和会大手町病院

国立小倉病院

社会保険久留米第一病院

町立芦屋中央病院
中間市立病院

福岡歯科大学附属病院

福岡遁信病院

三井大年田病院

宗像医師会病院

《佐賀県》

医療法人春陽会上村病院

唐津赤十字病院

国立嬉野病院

国立療養所東佐賀病院

佐賀社会保険病院

千葉内科病院

《長崎県》

医療法人栄和会泉川病院

医療法人春回会井上病院

医療法人祥仁会西諫早病院

医療法人白十字会佐世保中央病院

医療法人雄博会千住病院

北松中央病院

国民健康保険平戸市民病院

国立療養所川棚病院

三佼会宮崎病院

聖フランシスコ病院

長崎記念病院

長崎県済生会病院

長崎県立島原温泉病院

長崎市立病院成人病センター

《熊本県》

天草郡市医師会立天草地域医療センター 医療法人社団孔和会松本内科 - 眼科

医療法人社団坂梨会阿蘇温泉病院

健康保険人吉総合病院

NTT 西日本九州病院

(労) 熊本労災病院

《大分県》

医療法人社団仁泉会畑病院

大分県立病院

大分県済生会日田病院

膳所医院

《宮崎県》

県立宮崎病院

宮崎社会保険病院

《鹿児島県》

大隅鹿屋病院

鹿悲島県立鹿屋病院

鹿児島県立薩南病院

垂水市立医療センター垂水中央病院

出水郡医師会立阿久根市民病院

《沖縄県》

医療法人中部徳洲会中部徳洲会病院

医療法人博愛会牧港中央病院

沖縄県立北部病院

県立南部病院

ハートライフ病院

研修関連施設（計 285施設）

尚，施設一覧は2000年 2 月 29 日現在の情報を基に作成しております

今後名称等に変更が生ずる場合がございすすので，ご了承願います．また，今後新たに指定・辞退される施設もあります

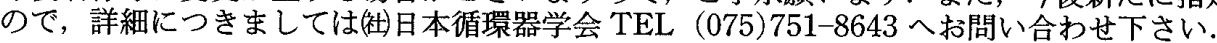

